\title{
Implementasi Digital Marketing dalam Membangun Brand Awareness
}

\author{
Femi Oktaviani ${ }^{1}$ dan Diki Rustandi ${ }^{2}$ \\ ${ }^{1,2}$ Universitas BSI
}

\begin{abstract}
ABSTRAK
Sentra industri rajutan Binong Jati sebagai industri kreatif di bidang fashion. Memproduksi berbagai jenis pakaian rajutan berskala home industry sejak tahun 60-an. Seiring dengan waktu sentra rajutan ini kemudian dikelola oleh Koperasi Industri Rajutan Binong Jati (KIRBI) dengan harap dapat meingkatkan dan membangun potensi kemampuan ekonomi anggota dan masyarakat dalam mencapai kesejahteraan. Kehadiran KIRBI sebagai wadah sekaligus garda terdepan para pelaku bisnis rajutan, seharusnya mampu mengembangkan potensi yang ada dengan mempromosikan wilayah Binong Jati menjadi salah satu industri kreatif, sehingga masyarakat mengetahui dan aware terhadap produk industri rajutan Binong Jati. Penelitian ini mengemukakan digital marketing dalam membangun brand awareness sebagai upaya menginformasikan, membujuk dan mengingatkan masyarakat tentang KIRBI sebagai salah satu UMKM pembuatan pakaian berbahan rajutan. Pemilihan social media, pesan, dan kegiatan bauran promosi yang digunakan KIRBI untuk membangun brand awareness menjadi tujuan dari penelitian. Penelitian ini sebagai penelitian kualitatif dengan menggunakan studi kasus. Data yang di dapat melalui observasi dan wawancara, serta didukung oleh dokumentasi peneliti. Informan terdiri dari dua informan utama dan dua informan tambahan. Hasil penelitian menunjukan bahwa digital marketing dalam membangun brand awareness dilakukan dengan mengelola media sosial instagram dengan melakukan aktivitas berupa iklan, tagline, serta menjalankan teknik bauran pemasaran seperti personal selling, sales promotion dan public relations sebagai upaya membangun brand awareness tentang produk industri rajutan Binong Jati.
\end{abstract}

Kata-kata Kunci: Brand awareness; digital; instagram; kirbi; marketing

\section{The Implementation of Digital Marketing in Building of Brand Awareness}

\begin{abstract}
The center of Binong Jati knitted industry is one of the creative industries engaged in the field of fashion. Producing the various types of knitwear in scale home industry since the 60's. Along with the time this knitted center is managed by Industrial Cooperation of Binong Jati Knitted (KIRBI) in the hope of developing the potential and economic ability of members and society in achieving the welfare. The presence of KIRBI as the tools and the forefront of the knit business people, should be able to develop the existing potential by promoting the area of Binong Jati become one of the creative industries, so that people know and aware of knitted products industry of Binong Jati. This research suggests the digital marketing in building brand awareness as an effort to inform, persuade and remind people about KIRBI as one of UMKM in making knitted garments. The purpose of this research is to know the selection of social media, message planning, and promotional mix activities used by KIRBI to build brand awareness. Researchers use qualitative research methods by using case study approach. Data collection techniques used through observation, interviews, and supported by the documentation of researchers. The informants from this study consisted of two main informants and two additional informants. The results showed that digital marketing in building brand awareness is done by managing social media Instagram by doing the activity in the form of advertisement, tagline, and running marketing mixing techniques such as personal selling, sales promotion and public relations as an effort to build brand awareness about knitted products of Binong Jati.
\end{abstract}

Keywords: Brand awareness; digital; instagram; kirbi; marketing

Korespondensi: Femi Oktaviani, M.I.Kom. Universitas BSI. Jl. Sekolah Internasional No. 1-6, Antapani, Bandung 40291. Email: femi.foi@bsi.ac.id 


\section{PENDAHULUAN}

Paris Van Java merupakan sebutan lain dari Bandung. Keindahan alam dan kesejukan udaranya banyak disukai oleh masyarakat luas. Tidak hanya itu Bandung terkenal sebagai kota fashion dengan model terbaru, sehingga tak heran jika Bandung menjadi acuan trend fashion dan salah satu destinasi wisata belanja di Indonesia. Salah satu rajutan kreatif yang berada di kota Bandung adalah Sentra industri rajutan Binong Jati, bergerak di bidang fashion yang berada di Bandung. Pakaian rajutan sangat cocok digunakan di daerah-daerah berudara sejuk, seperti Bandung. Kebutuhan akan pakaian, sarung tangan, syal, topi dan sebagainya yang terbuat dari rajut menjadi salah satu alasan terbentuknya industri rajutan Binong Jati.

Pada awalnya, kegiatan merajut di daerah Binong Jati hanya dilakukan oleh sebagian kecil ibu-ibu yang tidak bermata pencaharian. Mereka merajut hanya untuk mengisi kekosongan waktu. Rata-rata melakukannya dengan cara konvensional dan rajutan tangan, dan rupanya hasil rajutan mereka tidak mengecewakan. Dari hasil rajutan tersebut, kemudian pesanan semakin meningkat. Namun bukan berarti usaha merajut langsung melejit, bahkan dengan modal terbatas para pengrajut dapat menyelesaikan pesanana apabila bahan baku disediakan oleh pemesan. Besarnya minat masyarakat terhadap pakaian rajut, membuat seorang pengusaha Tionghoa mengajak para pengrajin rajut Binong Jati untuk bekerja sama. Oleh pengusaha tersebut, disediakan sejumlah modal dan mesin rajut modern untuk mempercepat pekerjaan. Dengan adanya mesin rajut modern, kuantitas rajutan semakin banyak dan bisa dipasok ke pasar-pasar. Sehingga dengan banyaknya pengrajin rajut di kawasan ini, masyarakat setempat berinisiatif menjadikan perkampungan sebagai sentra rajut dan terus berkembang sampai detik ini. Dalam mengembangkan potensi masyarakat pengrajin rajutan, masyarakat membentuk satu koperasi yang bernama KIRBI (Koperasi Industi Rajutan Binong Jati). KIRBI merupakan koperasi yang menaungi para pengusaha rajutan di Binong Jati. Fungsi dari koperasi itu sendiri yaitu untuk mengembangkan berbagai potensi serta ekonomi dari para anggota termasuk masyarakat dalam mencapai kesejahteraan. Selain itu, terbentuknya KIRBI sebagai wadah sekaligus garda terdepan para pelaku bisnis rajutan.

Namun pada kenyataanya, terbentuknya KIRBI tidak membuat produk yang dihasilkan para pengrajin rajut dikenal oleh masyarakat luas. Sehingga KIRBI memerlukan strategi komunikasi pemasaran yang dapat mengembangkan potensi para pengrajin dengan mempromosikan Binong Jati menjadi salah satu 
pemasaran sebagai suatu aktivitas di bidang pemasaran untuk memperluas informasi, memengaruhi atau mempersuasif produk yang dihasilkan suatu perusahaan supaya dapat diterima oleh masyarakat sebagai calon konsumen (Tjiptono, 2011). Dengan KIRBI melakukan komunikasi pemasaran diharapkan masayarakat umum khususnya di Bandung dan umumnya di Indonesia dapat mengetahui kawasasan Binong Jati sebagai sentra industri rajutan dan sadar akan hasil merek produk yang dihasilkannya.

Pada tahun 2007, pemerintah kota Bandung menetapkan tujuh sentra industri dan perdagangan di Bandung sejak tahun 2007. Binong Jati termasuk dalam tujuh sentra industri andalan kota Bandung selain diantaranya; sentra kain Cigondewah, sentra Jeans Cihampelas, sentra kaos Suci, sentra tahu Cibuntu, sentra boneka Sukamulya, dan sentra sepatu Cibaduyut. Sebagai salah satu dalam tujuh sentra industri andalan kota Bandung, sentra industri rajutan Binong Jati tidak kalah populer dengan sentra industri lain. Perkembangan jaman disertai dengan kemajuan teknologi, sarana promosi menjadi bertambah seperti melalui penggunaan media Internet. Dengan media ini, perusahaan tidak membutuhkan banyak biaya untuk mempromosikan produk, disamping jangkauanya yang sangat luas. Digital marketing merupakan pemanfaatan
Internet sebagai suatu teknologi yang dapat menghubungkan komunikasi dua arah di antara perusahaan dengan konsumen (Coviello, 2001).

Digital marketing memudahkan promosi penjualan, seperti penggunaan media sosial yang banyak digunakan oleh para pemasar. Begitu juga dengan KIRBI menggunakan pemasaran melalui digital marketing agar jangkauannya luas dan biaya lebih murah. Keberadaan media sosial menjadi sarana bagi konsumen yang dapat digunakan untuk menyebarkan informasi baik berupa teks, gambar, audio, dan video dengan banyak pihak baik antar perusahaan kepada konsumen atau konsumen pada perusahan (Kotler, 2012).

Berkembangnya teknologi dapat digunakan untu mengembangkan dunia bisnis. Salah satunya kegiatan komunikasi pemasaran mengharuskan memanfaatkan era digital dalam menguasai pangsa pasar. Konsep digital marketing adalah memanfaatkan area luas pada media seperti televisi, radio, perangkat mobile hingga Internet, dimana media tersebut akan memberikan infografis tentang berbagai produk yang dipasarkan oleh perusahaan, terutama penekanan tentang merek sebuah barang atau jasa. Digital marketing menjadi sarana paling ampuh untuk meroketkan merek akan suatu produk atau jasa.

Digital marketing dapat menjangkau semua kalangan, kapanpun, dengan cara apapun, dan 
dimanapun. Tentu sangat jauh lebih unggul dibandingkan dengan marketing konvensional yang terbatas waktu, lokasi, dan jangkauan pengguna. Hal ini diperkuat sebagaimana hasil penelitian dari Putri dan Fitrah (2017) yang menyatakan bahwa ada pengaruh antara kampanye online marketing dengan kebiasaan konsumen dalam memilih suatu barang atau jasa.

Media sosial merupakan media pilihan yang digemari oleh masyarakat. Hal ini didukung dengan keberadaan telepon seluler yang menyediakan fitur-fitur yang terhubung dengan Intrenet, sehingga siapapun dapat mengakses media sosialnya dengan cepat, mudah, dimanapun berada. Dengan teknologi komunikasi yang semakin berkembang membuat keterbukaan informasi serta pola penyebaran informasi juga ikut berubah. Produksi informasi saat ini dapat dilakukan oleh pihak yang tidak terlembagakan. Artinya saat ini siapapun seolah bebas menyebarkan informasi tanpa melalui gatekeeper. Hal tersebut harus mulai disadari bahwa media sosial saat ini dapat dikatakan memiliki kendali yang cukup tinggi untuk memengaruhi publik karena media sosial memiliki kekuatan yang cukup besar untuk memengaruhi publik yang terkadang tidak dapat dilakukan oleh suatu organisasi.

Selain itu, kemajuan teknologi dapat membuat informasi tersebar secara luas dan cepat sehingga masyarakat dapat mengetahui berbagai informasi tentang suatu produk atau jasa sebelum calon konsumen menentukan dan membeli produk-produk tersebut. Kemajuan teknologi khususnya bidang informasi melahirkan konsep baru terhadap bidang pemasaran. Banyak perusahaan menginformasikan sekaligus mempromosikan produknya hanya secara langsung di toko, namun sekarang dapat memanfaatkan teknologi sebagai sarana promosinya.

Akan tetapi, adanya jaringan Internet perusahaan bisa memasarkan produknya secara cepat dengan daya jangkau yang luas, seperti halnya KIRBI dalam mempromosikan produk rajutan. Dalam membangun kesadaran akan merek hasil dari produksi para pengrajin rajut Binong Jati, KIRBI memilih media sosial untuk melakukan kegiatan komunukasi pemasaran, dengan harapan dapat membangun hubungan dengan konsumen secara aktif, yang pada akhirnya merek dari pengrajin rajut binong jati dapat dikenal oleh masyarakat umum. Kegiatan promosi melalui media sosial diharapkan dapat menjadi fackor utama dalam meningkatkan serta mempertahankan brand awareness, dimana konsumen lebih aware dan ingat akan merek dari suatu produk yang dihasilkan perusahaan, yang pada akhirnya membuat konsumen menjadi loyal akan merek dan produk tersebut.

Brand awereness sebagai sebuah strategi 
pemasaran menjadi faktor paling penting dalam membangun kesadaran konsumen untuk membeli suatu produk. Melalui kesadaran konsumen atas suatu brand, maka calon konsumen dapat ingat dan kenal terhadap merek dan memutuskan melakukan pembelian, memungkinkan konsumen hanya melakukan pembelian kepada satu kategori merek tertentu saja. Istilah strategi sering kali dipakai masyarakat dalam memdeskripsikan suatu hal seperti beberapa tujuan yang ingin dicapai. Seperti halnya KIRBI dalam melakukan sebuah strategi untuk mencapai tujuan.

Media sosial seperti instagram adalah media sosial utama yang digunakan KIRBI untuk mempromosikan produk rajutanya. Sebuah aplikasi yang kekinian atau sering digunakan oleh masyarakat luas yaitu Instagram menjadi salah satu media sosial yang berfokus pada aktivitas atau kegiatan seseorang untuk disebar luaskan kepada masyarakat, sehingga masyarakat dapat mengetahui kegiatan seseorang atau perusahaan dari instagram yang digunakanya. Instagram dapat digunakan untuk memposting gambar atau foto. Feature yang unik dan bagus menjadikan instagram sebagai media sosial yang dapat menyimpan foto dalam jumlah banyak. Terdapat banyak filter dapat digunakan dalam menampilkan hasil gambar sehinga menjadi lebih bagus dari gambar sebelumnya. Sehingga dengan memiliki kelebihan yang terdapat pada media sosial Instagram ini, KIRBI menggunakan media sosial Instagram sebagai media digital marketing dalam mempromosikan produk rajutan Binong Jati. Menurut Shimp (2014) brand awareness yaitu kemampuan sebuah produk akan merek untuk selalu ingat dalam ingatan konsumen saat konsumen memikirkan berbagai produk tertentu dan dengan mudah suatu merek akan muncul dalam ingatannya. Dua tingkatan dalam kesadaran merek, pertama merek akan dikenal oleh konsumen (brand recognition) yaitu menunjukkan kesadaran yang dangkal terhadap suatu merek. Kedua ingat terhadap suatu merek (brand recall) yaitu tercermin bahwa suatu merek lebih diingat lebih dalam oleh konsumen.

Beberapa tahapan dalam brand awareness yaitu pertama, unaware of a brand, (merek yang tidak disadari) merupakan urutan paling bawah dalam piramid brand awareness, pada tahap ini konsumen sama sekali tidak sadar akan suatu merek. Kedua, brand recognition yaitu tahapan minimum brand awareness, pada tahap ini merek suatu produk dikenal kembali oleh konsumen dalam ingatannya (aided recall). Ketiga, brand recall yaitu suatu merek dapat diingat oleh konsumen secara mudah karena sudah disimpan dalam ingatan konsumen (unaided recall). Dan keempat, top of mind yaitu merek suatu produk yang langsung diucapkan oleh konsumen pada 
saat ingat terhadap suatu produk. Sehingga merek tersebut sudah tersimpan dalam ingatan konsumen.

Brand awareness sangat penting dalam bisnis apapun termasuk industri rajutan karena tidak hanya mengundang konsumen untuk membeli namun dapat membuat konsumen menjadi konsumen berulang (repeat custumer). Konsumen akan lebih mungkin membeli barang atau memakai jasa dari nama yang mereka percaya dan mudah dikenali, sehingga merek apa yang pertama kali muncul dalam benak konsumen, kemungkinan besar mereka juga akan membeli merek tersebut dan memberi tahu orang lain mengenai merek tersebut.

Digital marketing sebagai media promosi bertujuan untuk menyampaikan atau menyebarluaskan atau memasarkan tentang suatu produk sehingga dapat memengaruhi konsumen untuk membelinya. Kegiatan promosi dapat dilakukan lewat beriklan di media massa, face to face, promosi, door to door dan sebagainya. Membangun brand awareness melalui digital marketing merupakan hal yang sangat penting dari marketing sebuah merek seperti halnya produk industri rajutan. Salah satu hasil penelitian terdahulu yang berjudul "Importance of brand awareness and brand loyalty in assessing purchase intentions of customer" menunjukkan bahwa setiap 1 perubahan unit dalam brand awareness, niat pembelian akan dirubah sebesar 0.12 unit ke arah yang sama. Dengan kata lain kesadaran merek akan meningkatkan niat beli konsumen, niat pembelian memiliki hubungan positif yang kuat dengan brand awareness dan brand loyality. Niat pembelian dapat ditingkatkan dengan peningkatan brand awareness dan brand loyality (Malik, 2013).

Pada penelitian ini, digital marketing dalam membangun brand awareness KIRBI dilakukan melalui media sosial, tidak hanya produk yang menjadi fokusnya tetapi juga para konsumen. Melalui media sosial, sebuah merek dapat berinteraksi dengan para konsumen dan calon konsumen secara langsung. Dengan menciptakan brand experience yang sesuai dengan keinginan konsumen dan melibatkan mereka menjadi bagian dari brand narrative. Dimana hal ini dapat membantu untuk meningkatkan rasa percaya diri konsumen terhadap merek tersebut yang lebih sulit dibangun melalui cara-cara marketing dan advertising tradisional. Dalam media sosial juga dapat dilihat reaksi dan respons konsumen terhadap produk sehingga dapat menentukan atau menyesuaikan strategi promosi yang akan digunakan. Dalam menggunakan sosial media diperlukan juga menyusun strategi yang tepat. Pengelola akun media sosial harus aktif dan sering memposting tentang produk yang ditawarkan kepada konsumen dan 
tetap melakukan interaksi dengan followers. Disamping itu konten tentang media sosial harus menjadi perhatian, sehingga relevan dengan produk kita dan membuat banyak orang akan lebih tertarik membaca dan berinteraksi dengan media sosial yang kita miliki untuk mempromosikan produk.

Dalam kegiatan promosi, aspek pesan juga perlu direncanakan dengan baik dalam penyusunannya. Pesan dibuat dan disebarluaskan kepada komunikan, sehingga dapat memberikan atensi bagi komunikan ketika diterpa oleh pesan tersebut. Lambang verbal atau non verbal yang digunakan dalam pesan harus bisa dipahami oleh komunikator dan komunikan sehingga pesanya dapat diterima dengan baik dan menghasilkan feedback. Disamping itu, pesan dapat meningkatkan atau memenuhi kebutuhan personal komunikan serta memberikan manfaat bagi komunikan yang menerima pesan tersebut. Teori realitas sosial menjadi landasan dalam penelitian ini, yaitu membedakan antara apa yang dipahami dari kenyataan serta apa yang diketahui. Arti realitas sendiri yaitu mutu yang ada pada realitas dari apa yang dimiliki tanpa bergantung pada keinginannya. Sedangkan pengetahuan diartikan suatu kepastian dari kenyataan realitas itu sendiri ada (Bungin, 2013). Proses terjadinya dialektika yaitu jika antara individu membangun masyarakat, dan sebaliknya masyarakatpun menciptakan atau membangun individu. Tahapan dialektika berlangsung mulai dari eksternalisasi, objektivasi, serta internalisasi. Dalam menjalankan tahapan sosial lewat tindakan dan interaksinya, yang mana individu melakukan secara berkelanjutan pada suatu realitas baik melalui frame of reference maupun frame of experience individu secara subjektif. Setiap peristiwa atau kegiatan merupakan kenyataan sosial yang objektif dan fakta yang sebenarnya ada. Realitas sosial dalam membangun kampoeng radjoet ini dijalankan dan sebagai suatu realitas sosial subjektif seorang individu yang menyaksikan peristiwa tersebut dengan menggunakan digital marketing dalam membangun brand awareness. Dari uraian di atas, artikel ini memfokuskan pada kegiatan digital marketing dalam membangun brand awareness KIRBI (Koperasi Industri Rajutan Binong Jati).

\section{METODE PENELITIAN}

Metode penelitian yang digunakan dalam artikel ini yaitu kualitatif dengan memilih studi kasus sebagai pendekatan penelitian. Yang menjadi dasar dalam penelitian kualitatif adalah membentuk suatu pandangan dari para informan secara detail, yang diuraikan melalui kata-kata secara menyeluruh. Tujuan dati penelitian kualitatif yaitu untuk memahami apa yang terjadi di lapangan pada saat melakukan 
penelitian oleh peneliti seperti perilaku, persepsi serta motivasi, tindakan dan sebagainya, secara menyeluruh dan kompleks, kemudian memaparkanya melalui kata-kata yang mudah dipahami terhadap suatu hal yang bersifat alamiah serta menggunakan beberapa metode yang alamiah (Moleong, 2013). Pada penelitian ini, memaparkan suatu masalah yang berkaitan tentang pemahaman pengalaman individu saat dihadapkan pada suatu kejadian tertentu. Selain itu dapat menambah wawasan baruyang dapat diketahui melalui metode ini karena bisa membuka secara detail dan kompleks tentang digital marketing dalam membangun brand awareness.

Studi kasus merupakan pendekatan penelitian yang memfouskan kepada salah satu kasus tertentu yang dapat diamati serta dianalisis dengan cermat hingga tuntas. Melalui studi kasus peneliti dapat mengkaji lebih dalam dari suatu peristiwa dalam realitas kehidupan. Secara garis besar, studi kasus sebagai suatu cara yang lebih tepat menggunakan pertanyaan how atau why, jika peneliti hanya memiliki kesempatan yang terbatas untuk mengawasi kejadian yang sedang diteliti, dan jika fokus penelitian berada pada fenomena kontemporer pada situasi kehidupan yang nyata (Yin, 2002). Studi kasus tunggal pada penelitian ini menyoroti perilaku individu/ kelompok/ peristiwa dengan masalah penting dan peneliti sendiri merupakan instrument dalam penelitian untuk memperoleh informasi menyeluruh secara detail tentang digital marketing dalam membangun brand awareness. Di samping itu untuk mendalami secara mendalam mengenai aktivitas dan kebijakan yang dilakukan oleh KIRBI dalam melakukan digital marketing, dan brand awareness sebagai salah satu kegiatan komunikasi pemasaran yang dilakukan KIRBI dalam membangun kesadaran merek produk industri rajutan kepada masyarakat.

Objek dalam penelitian ini adalah digital marketing dalam membangun brand awareness, sedangkan subjek penelitianya adalah KIRBI (Koperasi Industri Rajutan Binong Jati). Data yang diperoleh didapat melalui observasi, wawancara, dokumentasi dan studi kepustakaan. Pada penelitian ini, untuk mendapatkan keabsahan data penilitian menggunakan triangulasi data yaitu menggabungkan beragam sumber data seperti, mengumpulkan data dari KIRBI dengan lokasi/latar, atau waktu yang berbeda-beda, serta beberapa referensi yang berasal dari informan lain atau gambar, rekaman, wawancara, dan catatan di lapangan.

Wawancara dilakukan setelah observasi dilakukan agar data yang diperoleh sesuai dengan hasil observasi tentang subjek penelitian. Wawancara dilakukan kepada humas dari KIRBI, pengrajin serta masyarakat sekitar. Informan ditentukan secara purposive sampling 
berdasarkan kriteria yang dibutuhkan sebagai sumber data penelitian. Lokasi penelitian dilakukan di sentra industri rajutan Binong Jati yang terletak di Jl. Binong Jati, Kecamatan Batununggal kota Bandung.

\section{HASIL DAN PEMBAHASAN}

Peran penting komunikasi pemasaran dalam suatu perusahaan adalah untuk memicu penjulan suatu produk yang dihasilkan perusahaan, sehingga konsumen mengetahui tentang produk tersebut. Pemasaran selalu berusaha untuk meningkatkan kualitas hubungan di antara perusahaan dengan konsumennya sehingga kesadaran akan konsumen terhadap produk atau jasa yang ditawarakan perusahaan dikenal melalui proses perencanaan dalam promosi, begitu juga dengan Koperasi Industri Rajutan Binong Jati dalam membangun brand awareness.

Perkembangan teknologi membuat media yang dapat digunakan untuk promosi menjadi banyak diantaranya melalui jaringan internet. Dengan jaringan ini, perusahaan akan sedikit mengeluarkan biaya sebagai jalan untuk memasarkan produk yang dihasilkannya, disamping jangkauannya yang sangat luas. Coviello, Milley \& Marcolin(2001)menjelaskan bahwa digital marketing adalah pemanfaatan jaringan Internet yang disertai dengan pemanfaatan teknologi yang bersifat interaktif yang dapat menghubungkan komunikasi dua arah di antara perusahaan dengan konsumen.

Digital marketing memudahkan promosi penjualan sehingga banyak perusahaan kini lebih canggih untuk memasarakan produknya. Satu diantaranya penggunaan media sosial. Begitu juga dengan KIRBI menggunakan pemasaran melalui digital marketing agar jangkauannya luas dan biaya lebih murah. Menurut Kotler (2012), media sosial adalah suatu sarana untuk konsumen dalam menyebarluaskan informasi baik berupa teks, gambar, audio, dan video yang terjadi diantara perusahaan dengan konsumennya. Pemanfaatan digital marketing dapat mengefesiensikan perusahaan terutama dalam biaya untuk memasarkan atau mempromosikan produk perusahaan, disamping jangkauannya yang sangat luas. Henderi (2007) menyatakan, media sosial merupakan suatu jaringan sosial yaitu layanan berbasis web yang dapat digunakan oleh individu untuk membuat profil publik atau semi-publik yang terbatas, daftar pengguna lain, serta siapa saja yang terhubung dengan perusahaan, dan dapat melihat dan menelusuri daftar koneksi mereka yang dibuat oleh orang lain dengan suatu sistem. Menurut Brogan (2010), social media is a new set communication and collaboration tools that nable many types of interaction that were previously not available to the common person. (Media sosial merupakan seperangkat baru 
dalam bidang komunikasi yang berkolaborasi, yang dapat melahirkan banyak interaksi atau komunikasi dua arah). Berdasarkan kedua definisi tersebut, dapat disimpulkan bahwa media sosial merupakan sarana penukaran informasi atau pesan di antara individu serta sebagai media untuk mempromosikan suatu produk yang dihasilkan oleh suatu perusahaan.

Internet marketing dalam marketing mix sebagai acuan dalam perkembangan pemasaran yang baru. Pemanfaatan Internet dapat merubah elemen marketing mix tradisional. Pemasaran dengan memanfaatkan Internet menjadi kunci keberhasilan karena sifatnya yang dapat interaktif, Internet sebagai suatu pendekatan berbeda dalam pemasaran internasional. Internet dapat dipahami sebagai sesuatu yang fundamental dari pemasaran massal menjadi pemasaran personal. Bauran pemasaran dengan memanfaatkan mediaterdiri dari 5P, diantaranya: product, price, personalization, promotion, serta place. Aktivitas melalui Internet marketing dapat memberikan peluang untuk mewujudkan kegiatan baru dalam pemasaran tradisional dari non elektronic bergeser menjadi electronic platform (Sutejo, 2016). Dalam menjalankan digital marketing, KIRBI melakukan kegiatan pemasaran menggunakan bauran pemasaran (marketing mix) yaitu product, price, place dan promotion.

Produk (product). Wisata "kampoeng radjoet" sebagai sebuah produk yang dibuat oleh koperasi industri rajutan Binong Jati dengan mengeluarkan sebuah tagline "education, tour, and shopping" menjadi sebuah program kerja KIRBI dalam memperkenalkan Binong Jati sebagai sebuah sentra industri yang potensial yang ada di kota Bandung. KIRBI ingin menciptakan sebuah inovasi tentang wisata edukasi yang mencakup seluruh proses dari awal bahan baku benang, proses merajut sampai pada tahap finishing, bukan hanya sebagai tempat wisata belanja akan tetapi nantinya Binong Jati menjadi kawasan wisata edukasi tentang bagaimana proses pembuatan rajutan. Program Wisata kampoeng radjoet ini dibuat setelah beberapa tahun terakhir pelaku usaha rajutan yang berada sentra industri rajutan Binong Jati terus berkurang karena kurang sehatnya persaingan pasar. Budaya penjualan konvensional yang hanya berfokus pada grosir Tanah Abang menjadikan para pengrajin bersaing secara tidak sehat, ditambah dengan dibukanya pasar bebas ASEAN sehingga setiap tahun jumlah pengrajin semakin berkurang karena kurangnya pangsa pasar. KIRBI selaku garda terdepan bertujuan ingin memperkenalkan sentra industri untuk memperluas pemasaran.

Pengaruh dari Internet marketing terlihat signifikan terhadap brand aawareness, semua ini dilatarbelakangi oleh hubungan brand awarensess terhadap frekuensi seberapa sering 
suatu informasi atau pesan tentang suatu produk diterima dan dikaji oleh konsumen dari suatu perusahaan (Azaria, 2014). Harapan KIRBI terhadap masyarakat luas atau konsumen ialah, bagaimana KIRBI sebagai koperasi yang menaungi para pengrajin rajut yang berada di Binong Jati, tidak hanya fokus pada penjualan konvensional. KIRBI mempunyai tujuan agar Binong Jati menjadi sebuah kampung wisata yang bukan hanya sekedar menjual produk, akan tetapi menjadi sebuah kampung wisata edukasi bagi masyarakat yang tertarik dengan bagaimana proses pembuatan pakaian rajut. bagi masyarakat atau konsumen yang datang ke KIRBI akan diajak berkeliling kawasan sentra industri dari awal mulai bahan baku, proses merajut hingga proses finishing sekaligus pengunjung diajak melakukan kursus merajut singkat bagi yang ikut dalam kegiatan tersebut. Price, penetapan harga, merupakan hal yang paling penting guna mendapatkan keuntungan dan menentukan kelangsungan hidup perusahaan. Dalam menentukan harga untuk ikut dalam program wisata "kampoeng radjoet" ini KIRBI mematok harga yang sangat terjangkau. Disamping program tersebut KIRBI mempunyai pabrik kecil yang memproduksi sendiri pakaian rajut dengan skala kecil dan juga mengambil beberapa produk dari pengrajin untuk dijual di kios milik KIRBI.

Penentuan harga wisata kampoeng radjoet masih dalam tahap promosi, karena program tersebut masih dalam masa memperkenalkan rajutan Binong Jati. Pengunjung hanya ditarik biaya untuk sekali kunjungan hanya lima belas ribu rupiah. Place, mengenai tempat atau lokasi menjadi salah satu perangkat dalam bauran marketing mix diartikan sebagai tempat dimana usaha dijalankan merupakan keuntungan bagi perusahaan untuk menjangkau konsumennya. Namun pengertian lebih luas place itu sendiri merupakan segala kegiatan penyaluran produk berupa barang maupun jasa dari perusahaan ke konsumen. KIRBI yang tertelak di Jl. Binong Jati merupakan sentra industri rajutan yang mayoritas dari penduduknya adalah para pengrajin rajutan dengan skala rumahan atau home industry.

Tempat sebagai salah satu perangkat atau wadah yang digunakan sebagai lokasi dimana suatu usaha akan dijalankan merupakan sebuah potensi perusahaan mendatangkan keuntungan serta menjangkau sasaran konsumennya. Dalam menjalankan digital marketing untuk memperkenalkan sentra industri rajutan Binong Jati, KIRBI dalam menjalakan kegiatan wisata kampoeng radjoet ditunjang dengan kesediaan para pengrajin rajut bekerja sama dan mempersilahkan KIRBI untuk memakai pabrik mereka sebagai objek wisata edukasi dan kantor yang menyatu dengan kios yang berada di jalan Binong Jati. 
Promotion. Promosi merupakan elemen paling penting dalam pemasaran, yaitu usaha dari perusahaan untuk menginformasikan, membujuk, mengingatkan, menambah nilai dan memengaruhi konsumen atau masyarakat. Dengan demikian konsumen dapat mengetahui produk serta jasa dari perusahaan, sehingga dengan kegiatan promosi yang baik diharapkan masyarakat atau konsumen menjadi loyal pada produk serta jasa suatu perusahaan. Kegiatan promosi yang dilakukan KIRBI adalah dengan melakukan promosi melaui media sosial dan melalui kegiatan-kegiatan yang diadakan oleh dinas Koperasi. Promosi merupakan suatu usaha dari perusahaan untuk menginformasikan, membujuk, mengingatkan, menambah nilai dan memengaruhi konsumen untuk membeli suatu produk perusahaan. KIRBI Dalam melakukan kegiatan promosi sering ikut kegiatan pameranpameran yang sering diadakan oleh dinas koperasi UMKM Kota Bandung sebagai induk koperasi KIRBI. Dalam menjangkau konsumenya secara langsung, KIRBI memfokuskan pada penggunaan media sosial Instagram sebagai saluran komunikasi untuk berinteraksi langsung dengan konsumenya.

Dengan demikian promosi berperan sangat penting dalam penyampaian informasi dari pihak perusahaan kepada konsumennya akan suatu produk atau jasa, sehingga tujuan dari perusahan untuk memengaruhi masyarakat atau konsumen mengetahui, mengenal serta loyal terhadap produk dan jasa perusahaan. Pada KIRBI, digital marketing diperlukan untuk menumbuhkan keasadaran akan merek (brand awareness) yang dilakukan melalui pelaksanaan promotion mix melalui media sosial instagram dan memperkenalkan program wisata 'kampoeng radjoet'.

Digital marketing sebagai suatu aktivitas pemasaran agar produk atau jasa lebih dikenal oleh calon konsumen dan sekaligus memengaruhi calon pembeli agar dapat membeli serta mengkonsumsi produk serta jasa perusahaan melalui media Intrenet. Pada KIRBI digital marketing dibuat untuk brand awareness pada masyarakat. Melalui digital marketing, KIRBI memilih instagram sebagai media promosi. Aktivitas yang dilakukan berupa iklan akan produk rajutan. Iklan menjadi sangat penting dalam komunikasi pemasaran karena individu dapat berkomunikasi langsung dengan perusahaan yang pada ujungnya dapat terjadi penyebaran informasi mengenai produk serta jasa dari suatu perusahan. Dalam hal ini, KIRBI menggunakan iklan dalam media sosial Instagram karena dianggap efektif karena biaya yang efisisen dan jangkauan tak terbatas. Alasan KIRBI memanfaatkan media sosial Instagram untuk mempromosikan produk rajutan antara lain; 1) media sosial Instagram memperluas jangkauan konsumen. Dengan 
adanya instagram ini, pengguna instagram dapat menambah informasi bagi konsumen mengenai berbagai produk yang dihasilkan KIRBI, yang akhirnya menimbulkan adanya pilihan, dan 2) promosi melalui media sosial Instagram ini menimbulkan kepercayaan bagi konsumennya karena banyak testimoni maupun komentar-komentar yang bermanfaat bagi pengguna untuk mengetahui informasi lebih. Gambar-gambar produksi rajutan dengan fitur HD tampil secara cantik di timeline sehingga menimbulkan kepercayaan dan minat yang besar bahwa KIRBI membuatnya bonafif dan produk rajutan yang berkualitas. 3) KIRBI juga memanfaatkan fitur video snapgram dan audio yang berkualitas sehingga membuat banyak orang mengetahui, ingat dan percaya pada produk rajutan yang dihasilkan oleh para pengrajin rajutan Binong Jati.

Fungsi dan peran media sosial Instagram ini dapat merubah seseorang melakukan komunikasi yang awalnya satu serta dua arah, bisa menjadi banyak arah. Media sosial menjadi saluran utama bagi KIRBI dalam melakukan interaksi dengan konsumen serta bagaimana cara membujuk masyarakat luas untuk mencari solusi tentang produk rajutan KIRBI agar masyarakat sadar akan merek tersebut.

Media sosial Instagram, kini sebagai salah satumedia promosiyang cukup efisien dan efektif serta tepat sasaran. Dengan memanfaatkan
Instagram informasi dapat disebarluaskan secara luas terutama tentang produk rajutan KIRBI. Disamping itu jangkauan konsumen lebih luas karena tidak terbatas oleh jarak. Digital marketing merupakan cara komunikasi dua arah yang dapat menimbulkan awareness dan engagement masyarakat terhadap produk dan merek tertentu (Purwana, 2017). Secara tidak langsung promosi melalui media sosial Instagram, memiliki kelebihan tersendiri, saat memasarkan produk melalui media sosial Instagram, masyarakat sudah dipastikan melek akan teknologi. Namun disamping digital marketing KIRBI juga melakukan personal selling untuk membangun brand awareness, walaupun kegiatan tersebut tidak dilakukan secara maksimal karena keterbatasan SDM yang dimiliki KIRBI untuk mempromosikan secara langsung kepada konsumen. Personal selling merupakan aktivitas promosi melalui interaksi secara langsung terhadap calon konsumen. Tujuan promosi melalui personal selling sebagai upaya dalam mencapai tujuan penjualan untuk mewujudkan komunikasi dua arah terhadap konsumen. Personal selling yang dilakukan KIRBI adalah dengan tersedianya kantor sekaligus kios yang memajang berbagai produk rajutan sehingga konsumen dapat langsung berinteraksi dengan anggota KIRBI. Jadi pelaku pada kegiatan personal selling ini, hanya dilakukan oleh para anggota pengurus 
KIRBI.

Penggunaan sosial media sebagai sarana untuk menjalin industri rumahan. Media sosial yang banyak digunakan adalah facebook, whatsapp, Instagram, dan blackberry massanger. Manfaat yang dirasakan adalah komunikasi dengan para pelanggan dan pemasok lebih intens serta efektif dan efisien, karena dapat berkomunikasi langsung selama $24 \mathrm{jam} /$ real time (Pradiani, 2017).Dalam melakukan digital marketing, KIRBI mengadakan kegiatan promosi penjualan yaitu sebagai salah satu upaya agar konsumen tertarik untuk membeli produk rajutan. Aktivitas promosi selalu dilakukan oleh pelaku bisnis sebagai suatu cara untuk menghubungkan produk dengan segmentasinya secara langsung. Kegiatan ini, untuk berbagai insentif diberikan kepada calon konsumen sehingga calon konsumen bisa merasakan produk yang ditawarkan. Selain itu, melakukan kerja sama dengan dinas koperasi UMKM Kota Bandung untuk mengikuti pameran yang diadakan di beberapa kota besar Indonesia. Disamping itu, KIRBI juga mengadakan pelatihan merajut bagi merajut pakaian rajutan tersebut. Dengan adanya program tersebut, konsumen dapat memberikan testimoni pada media Instagram tentang pengalaman konsumen membeli sekaligus mengikuti pelatihan membuat rajutan, sehingga pada akhirnya masyarakat semakin aware terhadap rajutan Binong Jati.

Dalam upaya membangun brand awareness di masyarakat, KIRBI juga mengupayakan kegiatan public relations. Dimana public relation berperan dalam membangun citra dan reputasi perusahaan di mata konsumen atau masyarakat tentang produksi hasil rajutan Binong Jati. Adanya image baik di mata konsumen atau masyarakat dapat membuat produk rajutan Binong Jati menjadi incaran calon konsumen. Hubungan internal dan ekternal KIRBI dalam mewujudkan hubungan baik dengan publik internal serta eksternal guna meningkatkan image baik perusahaan. Publik internal dari KIRBI ialah para anggota organisasi dan pegawai yang bekerja di rumah produksi. Serta untuk publik eksternal, KIRBI menjalin hubungan dengan "Paguyuban Pribumi” yaitu perkumpulan yang dibuat para pengrajin dan dinas koperasi KUKM PERINDAG kota Bandung dan masyarakat. Public relations ini merupakan salah satu usaha lainnya dalam rangka meweujudkan serta mempertahankan hubungan yang baik dan bernilai guna di antara perusahaan dengan khalayak. Penggunaa media sosial digunakan sebagai sarana untuk berinteraksi langsung dengan konsumen. Memanfaatkan digital marketing dapat memberikan dampak positif bagi perusahaan salah satu diantaranya menciptakan komunikasi dua arah, sehingga feedback dapat diketahui 
secara langsung, sehingga perusahaan dapat mewujudkan hubungan baik dengan konsumen. Dalam melakukan pemasaran langsung, KIRBI menggunakan katalog di Internet dan media sosial Instagram yang sedang menjadi trend di kalangan masyarakat dunia khususnya di Indonesia karena dianggap mampu menginformasikan secara efektif, mudah, dan murah. Media sosial memiliki beberapa karakteristik diantaranya; 1) jangkauannya yang luas 2) aksesibilitas, dapat digunakan secara mudah oleh masyarakat dengan biaya yang rendah 3) mudah digunakan oleh siapa saja 4) aktualitas, menimbulkan respons yang cepat dari masyarakat 5) permanen, memudahkan dalam mengedit saran atau masukan dari berbagai pihak.

Melakukan digital marketing yang harus diperhatikan adalah pesan, komunikator dan audience. Seorang komunikator diharapkan dapat memilih jenis saluran yang digunakan dalam kegiatan komunikasi sehingga proses komunikais dapat berjalan efektif. Menyampaikan sebuah pesan agar tujuan dari pesan yang akan disampaikan akan dapat diterima dan dimengerti oleh audiens atau khalayak. Dalam membangun kesadaran merek, sentra industri rajutan Binong Jati mulai menggunakan media Internet untuk memperkenalkan serta mendorong penjualan secara online, agar yang semula hanya secara konvensional lewat toko, secara bertahap setelah menggunakan media Internet mendapat pangsa pasar yang lebih besar.

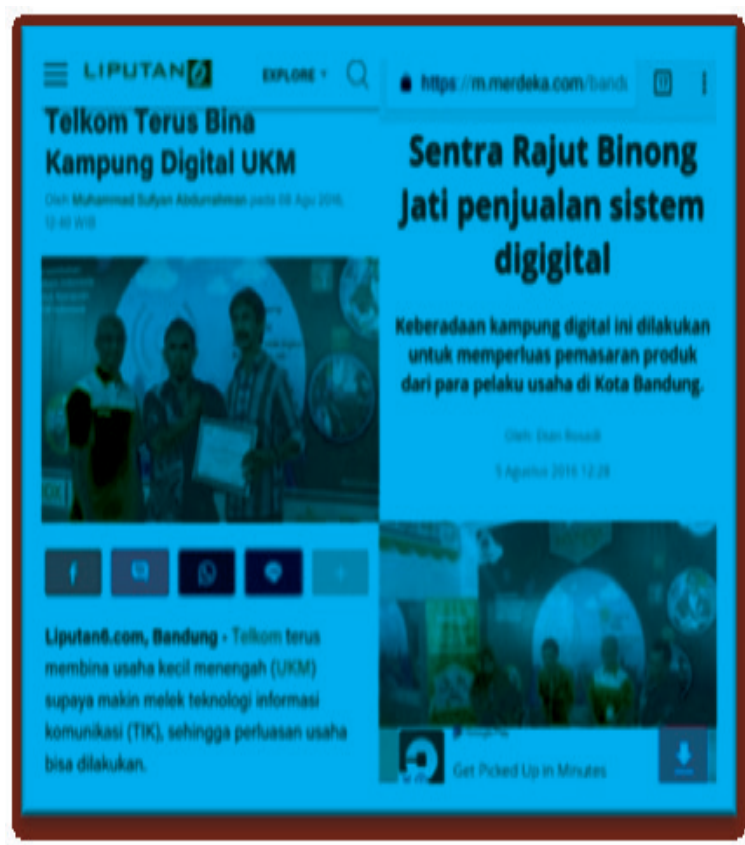

Sumber: Liputan 6.com (11/18/2017)

Gambar 1 Tampilan Berita di Media Online

Salah satu program BUMN untuk memajukan perekonomian adalah dengan mengadakan program 'kampung digital' yang bergerak di sektor teknologi informasi dan informasi diharapkan memacu untuk para pelaku usaha rajutan di Binong Jati semakin melebarkan penjualan tidak hanya terbatas hanya pada penjualan konvensional. KIRBI dalam rangka memperkenalkan sentra industri rajutan Binong Jati memfokuskan pada media sosial sebagai salah satu saluran dalam melakukan komunikasi untuk menyampaikan pesan kepada khalayak karena dinilai mudah, 
murah, dan cepat. Peran digital marketing dalam eksistensi bisnis dapat terwujud dengan baik apabila didukung dengan pemahaman perilaku konsumen yang sesuai dengan perkembangan teknologi yang terbaru (Nadya, 2016).

Memanfaatkan digital marketing bagi KIRBI memberikan banyak keuntungan diantaranya; 1) dapat menjangkau berbagai lapisan masyarakat khususnya masyarakat Bandung dan umumnya masyarakat Indonesia tentang industri rajutan Binong Jati. Kini masyarakat sudah sedikit yang menggunakan iklan baris untuk mencari informasi tentang suatu produk yang mereka butuhkan, karena banyak dari masyarakat memanfaatkan Intrenet dalam mencari berbagai informasi tentang produk yang dibutuhkan. Bermunculannya berbagai channel dalam digital marketing, perusahaan dapat membidik khalayak dengan cepat karena jaringan Internet yang begitu cepat dan dapat diakses dengan mudah oleh khalayak dimanapun dan kapanpun. Dalam hal ini, KIRBI memanfaatkan digital marketing melalui media sosial agar masyarakat mengenal dan aware terhadap hasil industri rajutan Binong Jati. 2) digital marketing membuat dana lebih hemat dan efisien. Keterbatasan dana yang dimiliki oleh KIRBI untuk mempromosikan produk industri rajutan dapat diatasi dengan memilih strategi ini. Tingginya penggunaan Internet di semua kalangan membuat peluang baru untuk KIRBI dalam memasarkan hasil industri rajutanya.

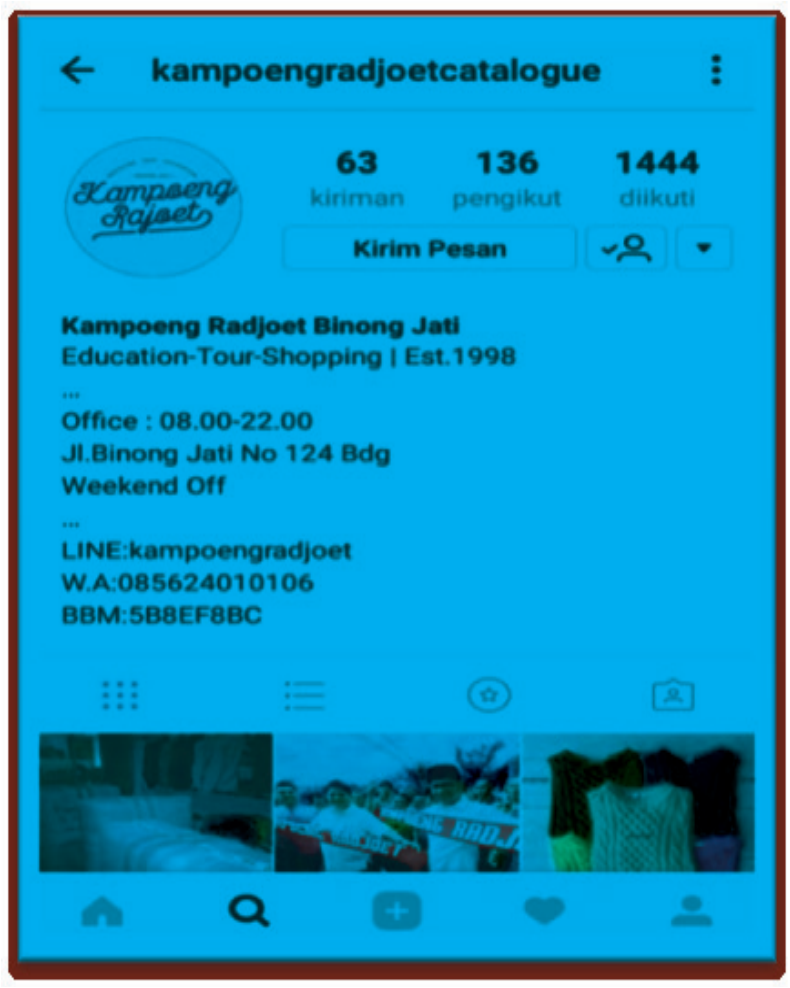

Sumber: Instagram KIRBI

\section{Gambar 2 Media Sosial KIRBI}

Digital marketing melalui media sosial Instagram sebagai saluran komunikasi yang menjadi fokus utama dari KIRBI dalam menunjang proses penyampaian informasi terhadap konsumennya. Guna memperkenalkan produk dan jasa perusahaan meskipun terkendala sumber daya, diharapakan dengan trend media instagram informasi yang disampaikan KIRBI dalam membangun kesadaran akan sentra industri rajutan Binong Jati dapat mudah dan cepat diterima oleh masyarakat luas. Dalam menjalankan digital 
marketing dalam membangun brand awareness KIRBI mengalami beberapa hambatan, baik internal maupun eksternal. Kurangnya sumber daya manusia sebagai faktor internal dan sebagian pengrajin yang menolak bekerja sama sekaligus kurangnya fasilitas dan infrastruktur yang memadai menjadi hambatan eksternal dari KIRBI. Akan tetapi dengan kepercayaan konsumen akan produk dan jasa KIRBI, program wisata kampoeng radjoet dapat berjalan walau dengan segala kekurangan, akan tetapi diharapkan dengan terus berjalannya program tersebut dapat menjadi perhatian bagi semua pihak untuk meningkatkan segala fasilitas dan infrastruktur agar Binong Jati bisa dikenal secara luas. Untuk melaksanakan sebuah program kerja akan selalu ada hambatan yang akan dihadapi oleh setiap perusahaan. Baik itu dari internal maupun eksternal. Hambatan KIRBI yang meliputi kurangya sumber daya manusia dan infrastruktur yang kurang memadai diharapkan menjadi motivasi KIRBI untuk menjadi lebih baik dalam pelayanan terhadap konsumen.

Teori yang mendukung saat melakukan penelitian ini adalah teori konstruksi realita sosial dinilai sangat mendukung bagi peneliti untuk melakukan penelitian mengenai digital marketing dalam membangun brand awareness koperasi industri rajutan Binong Jati. Menurut Berger dan Luckman terjadinya dialetika diantara individu dapat mewujudkan masyarakat begitu pula sebaliknya masyarakat dapat menciptakan individu. Dialetika terjadi dengan proses eksternalisasi dan objektivasi serta internalisasi. Memberikan gambaran tentang suatu proses sosial dengan tindakan serta interaksi, selain itu individu juga dapat mewujudkan realitas dari apa yang terjadi sesuai realitas dan subjektif (Bungin, 2013).

Eksternalisasi, sebagai suatu usaha untuk mengekspresikan mental dan fisik manusia dalam kehidupannya. Proses terjadi sebagai bentuk ekpresi individu dalam membangun eksistensi. Koperasi Industri Rajutan Binong Jati dalam masyarakat. Pada tahap ini KIRBI menciptakan produk wisata kampoeng radjoet. 2) objektivasi, merupakan apa yang didapat, baik secara mental atau fisik yang berasal dari aktivitas eksternalisasi individu. Pada tahap tersebut, masyarakat dipandang sebagai realitas yang objektif, dimana hubungan sosial dalam kehidupan individu dengan masyarakat diperoleh melalui proses institusional. Dalam hal tersebut terjadi proses interaksi sosial guna menginformasikan dan memasarkan produk dan membuat digital marketing membangun brand awareness. 3) internalisasi, yaitu memahami pengalaman secara objektif ke dalam alam sadar individu sehingga subjektivitas seorang individu terpengaruh oleh struktur sosial.

Dengan digital marketing yang dilakukan KIRBI dalam membangun brand awareness 
terhadap masyarakat sekitar secara tidak sadar telah dipengaruhi sehingga mereka mengakui dan merasakan suatu produk yang ditawarkan oleh individu yang berada di dalam lembaga tersebut.

Kaitan teori kontruksi realitas sosial dengan fokus penelitian ini adalah bagaimana mengungkap aktivitas sosial dengan berbagai aktivitas serta interaksinya. Selain itu seorang individu dapat membangun atau mewujudkan suatu realitas dari apa yang terjadi dalam kehidupan sosialnya secara subjektif. Setiap peristiwa atau kegiatan sebagai realitas sosial yang objektif serta sebagai suatu fakta sesungguhnya. Realitas sosial dalam membangun kampoeng radjoet ini diterima dan diinterpretasikan sebagai realitas sosial subjektif dalam individu yang menyaksikan peristiwa tersebut dengan menggunakan digital marketing mulai dari pemilihan media sosial, bentuk promosi, dan perencanaan pesan dalam upaya membangun brand awareness masyarakat terhadap industri rajutan Binong Jati.

\section{SIMPULAN}

Simpulan dari penelitian ini tentang implementasi digital marketing dalam membangun brand awareness produk KIRBI yaitu dengan cara menentukan media sosial yang akan digunakan, perencanaan pesan, dan menentukan teknik bauran promosi yang akan digunakan. Instagram merupakan media sosial yang dipilih oleh KIRBI untuk mempromosikan sekaligus membangun kesadaran merek industri rajutan Binong Jati di mata konsumen. Aktivitas yang dilakukan berupa iklan akan produk rajutan. Iklan menjadi sangat penting dalam komunikasi pemasaran yang dapat menjangkau masyarakat luas dan dapat menyebarluaskan informasi secara luas dan cepat tentang produk dari suatu perusahaan. Dalam hal ini, KIRBI menggunakan iklan dalam media sosial Instagram karena dianggap efektif karena biaya yang efisien dan jangkauan yang tak terbatas. Gambar-gambar produksi rajutan dengan fitur HD tampil secara cantik di timeline sehingga menimbulkan kepercayaan dan minat yang tinggi bahwa KIRBI membuatnya bonafid dan produk rajutan yang bermutu. KIRBI juga memanfaatkan fitur video snapgram dan audio yang berkualitas sehingga menjadikan masyarakat tahu, ingat serta percaya pada produk rajutan yang dihasilkan oleh para pengrajin rajutan Binong Jati.

Perencanaan pesan, dilakukan dengan membuat tagline "education, tour, and shopping" menjadi sebuah program kerja KIRBI dalam memperkenalkan Binong Jati sebagai sebuah sentra industri yang potensial yang ada di kota Bandung. Selanjutnya KIRBI juga mendirikan wisata kampoeng radjoet, serta menggunakan bauran promosi meliputi 
periklanan, penjualan langsung, promosi serta public relations dalam upaya membangun kesadaran akan merek tentang sentra industri rajutan Binong Jati. Dalam membangun brand awareness KIRBI tidak lepas dari hambatan, yaitu terbagi menjadi faktor internal dan eksternal. Hambatan faktor internal, kurangnya sumber daya manusia sehingga untuk mencapai tujuan visi dan misi KIRBI bergerak lambat. Faktor eksternal, infrastruktur yang kurang memadai dari mulai akses masuk ke kawasan hingga kurang bersahabatnya beberapa pengrajin karena rumah produksinya tidak ingin terganggu dengan kegiatan yang dibuat oleh KIRBI. Adapun rekomendasi yang dapat disampaikan antara lain: digital marketing pada pemasaran produk sebaiknya menjadi referensi untuk para pebisnis dalam memasarkan produk yang dihasilkan suatu perusahaan agar lebih dikenal secara luas oleh masyarakat. Selain itu, digital marketing akan lebih optimal apabila ditunjang dengan pemasaran mulut ke mulut yang positif agar memberikan dampak positif pula bagi kemajuan perusahaan/organisasi. Selanjutnya, diharapkan KIRBI melakukan aktivitas tambahan untuk kemajuan perusahaan seperti mengikuti pelatihan tentang digital marketing, merekrut SDM yang expert di bidang komunikasi pemasaran khususnya, menjalin kerjasama yang saling menguntungkan antar pihak, serta memperbaiki Sumber Daya
Manusia (SDM) KIRBI, agar publik dapat mengetahui dan tertarik dengan program kerja yang dilakukan, meningkatkan kualitas dan fasilitas agar konsumen semakin mempercayai produk dan loyal terhadap produk, dan terus berupaya menjalin hubungan lebih baik dengan pemerintahan agar segala infrastruktur yang dibutuhkan dapat segera terealisasi.

\section{DAFTAR PUSTAKA}

Azaria, P. A. (2014). Internet marketing terhadap pembentukan word of mouth dan efektivitas iklan dalam meningkatkan brand awareness. Jurnal Administrasi Bisnis (JAB), Vol. 13 No. 1 Agustus 2014. Bungin, B. (2013). Sosiologi komunikasi (teori, paradigma, dan discourse, teknologi komunikasi di masyarakat). Jakarta: Kencana Prenada Media.

Brogan, C. (2010). Social media 101: tactics and tips to develop your business online. Jon Wiley \& Sons.

Coviello, N. Milley, R. \& Marcolin, B. (2001). Understanding it-enable interactivity in contemporary marketing. Journal of Interactive Marketing, Vol. 15 No. 4, P. 1833.

Henderi, M. Y. \& Yuliana, I. G. (2007). Pengertian media sosial, (online), http:// wlipurn.blogspot.co.id/2018/02/wlipurn. html. (diakses pada Februari 2018).

Kotler, P. (2012). Manajemen pemasaran edisi 12. Jakarta: Indeks

Kotler, P. \& Kevin, L. K. (2012). Marketing management 13. New Jersey: Pearson Prentice Hall, Inc.

Malik, M. E. (2013). Importance of brand 
loyalty in assessing purchase intentions of customer. International Journal of Business and Social Science, Vol.04 No. 05.

Moleong, L. (2013). Metode penelitian kualitatif. Bandung: Remaja Rosdakarya.

Nadya. (2016). Peran digital marketing dalam eksisitensi bisnis kuliner seblak jeletet murni. Jurnal Riset Manajemen dan Bisnis, Vol. 1 No. 2, Oktober 2016: 133-144.

Pradiani, T. (2017). Pengaruh sistem pemasaran digital marketing terhadap peningkatan volume penjualan hasil industri rumahan. JIBEKA Vol. 11 No. 2 Februari 2017: 4653.

Purwana, E. S \& Dedi. (2017). Pemanfaatan digital marketing bagi usaha mikro, kecil dan menengah (umkm) di kelurahan malaka saei, duren sawit. Jurnal Pemberdayaan
Masyarakat Madani (JPMM), Vol. 1 No. 1 Juli 2017.

Putri, S. D. \& Fithrah, D. S. ( 2017). Pengaruh online marketing campaign \#samyangchallenge terhadap consumer behavior digital natives pengguna youtube Indonesia. Jurnal PRofesi Humas, 1 (2), 132-141.

Shimp, T. A. (2014). Komunikasi pemasaran terpadu dalam periklanan dan promosi. Jakarta: Salembat Empat.

Sutejo, B. S. (2016). Internet marketing: konsep dan persoalan baru dunia pemasaran. Jurnal Manajemen, Vol. 6 No. 1 November 2016.

Tjiptono, F. (2011). Pemasaran jasa. Sleman: Bayumedia Publishing.

Yin, K. R. (2011). Study kasus: desain dan metode. Jakarta: Raja Grafindo Persada. 